\title{
KEARIFAN LOKAL PANTAI LAUT SELATAN (MITOS NYI RORO KIDUL) SEBAGAI DESA WISATA DAN ASSET KABUPATEN SUKABUMI
}

\author{
Yuri Rahayu \\ NIDN: 0428087202 \\ Dosen AMIK BSI Sukabumi \\ Yuri.yru@bsi.ac.id
}

\begin{abstract}
Hearing the southern sea coast people will immediately think queenly figure, namely the southern coast guard Nyi Roro Kidul although the story will kebenerannya is still in question. Local knowledge is maintained continuity able to sustain life would be a tourist attraction and can increase the assets of government and society around. Local knowledge is a form of human effort in order to maintain, manage and preserve the indigenous culture and using his intellect (cognition) to act and behave towards something, objects or events that occur in a given space and dimension criteria to qualify as local wisdom. Qualitative research method is the right choice for this research because it aims to understand a phenomenon in the social context naturally. By having the natural attractions that are unique and distinctive and myths Nyi Roro Kidul attached, Pelabuhan Ratu eligible criteria of the tourist village and has the potential to bring assets and contribute in generating economical resources which are expected to provide benefits for the future and survival of the government and surrounding communities.
\end{abstract}

Keywords: Asset, myth nyi Roro Kidul, tourist villages, local wisdom.

PENDAHULUAN

Minimnya bukti sejarah dan simpang siurnya informasi yang ada membuat cerita kisah asal usul Nyi Roro Kidul masih sebuah misteri. Bicara tentang Nyi Roro kidul memang tidak ada habisnya. Ada pro kontra mengenai cerita mistis ini. Benar atau tidak masih sulit untuk di buktikan kebenarannya, apalagi bagi yang menganut agama muslim sepertinya mitos Nyi Roro Kidul hanya sebuah kemusrikana saja, tapi kenyataannya dan tidak bisa dipungkiri mitos tersebutlah yang membuat orang penasaran dan ingin berkunjung ke Pelabuhan Ratu dan ingin mengintif benar tidaknya sosok Nyi Roro kidul tersebut. Banyak pendapat di masyarakat terkait siapa sebetulnya Nyi Roro Kidul itu hingga akhirnya ia bisa menjadi penguasa gaib di
Laut Selatan Jawa (http://kisahasalusul.blogspot.com, 2015). Kearifan lokal dapat diartikan sebagai kebiasaan dan tradisi yang dipegang teguh oleh masyarakat sekitar untuk menjaga keaslian suatu budaya (Suryani, 2014). Sedangkan yang dimaksud dengan Desa Wisata adalah sebuah desa yang memiliki potensi untuk berkontribusi dalam menghasilkan asset karena keunikan dan daya tarik wisata yang khas. Pelabuhan Ratu memenuhu kreteria sebagai desa wisata karena memiliki fakta yang bisa masuk ke dalam syarat desa wisata diantaranya sebagai berikut : Pantai Pelabuhan Ratu, Scuba Diving, Goa Lalay, Pantai Cimaja, Karang hawu, Pemandian air panas Cisolok. Asset merupakan sebuah sumber ekonomi yang diharapkan dapat 
memberikan manfaat usaha di masa yang akan datang (gurupendidikan.com, 2016). Dengan memiliki obyek wisata alam yang unik dan khas dan mitos Nyi Roro Kidul yang melekat Pelabuhan Ratu memenuhi syarat kreteria desa wisata dan memiliki potensi untuk mendatangkan asset dan berkontribusi dalam menghasilkan sumber ekonomi yang diharapkan dapat memberikan manfaat untuk masa yang akan datang dan kelangsungan hidup pemerintahan dan masyarakat sekitar. Maka dari itu untuk bisa meningkatkan asset jumlah kunjungan wisata di kabupaten Sukabumi khususnya di Pelabuhan Ratu maka perlu di kaji sebuah penelitian yang mengangkat judul “ Kearifan Lokal Pantai laut selatan (Mitos Nyi Roro Kidul) sebagai Desa Wisata dan asets Kabupaten Sukabumi”,

\section{LITERATUR REVIEW}

\section{Kearifan Lokal}

Kearifan lokal menurut (UndangUndang N0. 23, 2009) tentang perlindungan dan pengelolaan lingkungan hidup $\mathrm{B} A B$ pasal 1 butir 30 adalah "nilai-nialai luhur yang berlaku dalam tata kehidupan masyarakat untuk antara lain melindungi dan mengelola lingkungan hidup secara lestari”. Definisi lain (Ridwan, 2007) tentang kearifan lokal atau sering disebut local wisdom dapat dipahami sebagai usaha manusia dengan menggunakan akal budinya (kognisi) untuk bertindak dan bersikap terhadap sesuatu, objek atau peristiwa yang terjadi dalam ruang tertentu. Pengertian tersebut disusun secara etimologi di mana wisdom dipahami sebagai kemampuan seseorang dalam bertindak atau bersikap sebagai hasil penelitian terhadap sesuatu, objek atau peristiwa yang terjadi . Hal senada diungkapkan juga oleh (Suryani, 2014) yang di maksud dengan kearifan lokal adalah pandangan hidup dan pengetahuan serta berbagai strategi kehidupan yang berwujud aktivitas yang dilakukan oleh masyarakat lokal dalam menjawab berbagai masalah dalam memenuhi kebutuhan mereka, meliputi seluruh unsur kehidupan, agama, ilmu dan teknologi, organisasi sosial bahasa dan komunikasi serta kesenian.

Dimensi dalam kearifan lokal masih menurut (Suryani, 2014) memiliki empat di mensi yaitu :

1. Dimensi pengetahuan lokal.

2. Dimensi nilai lokal.

3. Dimensi keterampilan lokal.

4. Dimensi sumber daya lokal.

Maka dapat di simpulkan bahwa yang di maksud dengan kearifan lokal adalah suatu bentuk usaha manusia dalam upaya menjaga, mengelola dan melestarikan budaya asli dengan menggunakan akal budinya (kognisi) untuk bertindak dan bersikap terhadap sesuatu, objek atau peristiwa yang terjadi dalam ruang tertentu dan memenuhi syarat sebagai dimensi kreteria kearifan lokal.

\section{Desa Wisata}

Desa Wisata adalah desa yang memiliki potensi keunikan dan daya tarik wisata yang khas, baik berupa karakter fisik lingkungan alam pedesaan maupun kehidupan sosial budaya kemasyarakatan yang dikelola dan dikemas secara menarik dan alami dengan pengembangan fasilitas pendukung wisatanya, dalam suatu tata lingkungan yang harmonis dan pengelolaan yang baik dan terencana sehingga siap untuk menerima dan menggerakkan kunjungan wisatawan ke desa tersebut,serta mampu menggerakkan aktifitas ekonomi pariwisata yang dapat meningkatkan 
kesejahteraan dan pemberdayaan masyarakat setempat (Muliawan, 2008 dalam Atmoko, 2016).

Kreteria desa wisata masih menurut Muliawan (2008) dalam (Atmoko, 2016) adalah sebagai berikut :

1. Memiliki potensi keunikan dan daya tarik wisata yang khas (sebagai atraksi wisata), baik berupa karakter fisik lingkungan alam pedesaan maupun kehidupan sosial budaya kemasyarakatan.

2. Memiliki dukungan dan kesiapan fasilitas pendukung kepariwisataan terkait dengan kegiatan wisata pedesaan, yang antara lain dapat berupa: akomodasi/penginapan, ruang interaksi masyarakat dengan wisatawan atau tamu, atau fasilitas pendukung lainnya.

3. Memiliki interaksi dengan pasar (wisatawan) yang tercermin dari kunjungan wisatawan ke lokasi desa tersebut.

4. Adanya dukungan, inisiatif dan partisipasi masyarakat setempat terhadap pengembangan desa tersebut terkait dengan kegiatan kepariwisataan (sebagai desa).

Maka dapat di seimpulakan bahwa yang di maksud dengan Desa Wisata adalah sebuah desa yang memiliki potensi untuk berkontribusi dalam menghasilkan asset karena keunikan dan daya tarik wisata yang khas.

\section{Asset}

Kriteria utama suatu asset adalah memberikan manfaat ekonomi masa untuk masa yang akan datang yang berpotensi untuk memberikan sumbangan, baik langsung maupun tidak langsung kepada entitas. Secara ekonomi manfaat suatu asset dapat di implementasikan dengan cara : (Muzayana, 2016)

a. Sebagai alat produksi untuk menghasilkan barang atau jasa

b. Dipertukarkan dengan asset lain

c. Untuk menyelesaikan masalah Liabilities

d. Dibagikan kepada pemilik entitas

Jika harus di klasifikasikan asset memiliki beberapa kelompok yaitu kelompok Aseets Lancar (Curent asset), aktiva tetap (Fixed asset dan asset tidak berwujud (intangible asset). Assets tidak berwujud yang bisa berbentuk patent, goodwill maupun image. Perbedan penggolongan tersebut akan Nampak di Laporan Keuangan. Sementara pengertian Asset menurut FASB dalam (Ningsih, 2001) adalah kemungkinan manfaat ekonomis di masa yang akan datang yang dikuasai atau di kendalikan oleh suatu entitas sebagai hasil dari transaksi atau kejadian di masa lalu. Dari beberapa pengertian di atas, maka dapat di tarik kesimpulan, yang di maksud dengan asset adalah kemampuan secara ekonomis dari suatu transaksi yang mampu memberikan manfaat untuk kelangsungan hidup perusahaan.

\section{METOE PENELITIAN}

Penelitian kualitatif adalah suatu penelitian ilmiah, yang bertujuan untuk memahami suatu fenomena dalam konteks sosial secara alamiah dengan mengedepankan proses interaksi komunikasi yang mendalam antara peneliti dengan fenomena yang diteliti (Herdiansyah, 2010). Sementara (Sugiono, 2012) berpendapat bahwa Peneliti kualitatif harus bersifat "perspektif emic" artinya memperoleh data bukan "sebagai mana seharusnya", bukan berdasarkan apa yang 
difikirkan oleh peneliti, tetapi berdasarkan sebagaimana adanya yang terjadi di lapangan, yang dialami, dirasakan dan difikirkan oleh partisipan.

\section{HASIL PENELITIAN DAN PEMBAHASAN}

Secara administratif, Pelabuhan Ratu adalah sebuah kecamatan yang terhimpun dari Sembilan desa dan satu kelurahan. Letak geografinya yang berbatasan langsung dengan perairan lepas Samudera hindia menyuguhkan sejumlah pesona wisata. Dari Jakarta jarak perjalanan ke Pelabuhan Ratu mencapai sekitar 137 Km sedangkan dari Bandung berjarak $153 \mathrm{Km}$ Pada zaman Hindia-Belanda, Pantai Pelabuhan Ratu Sukabumi dikenal dengan sebutan Wijnkoops-Baai. Pelabuhan Ratu merupakan nama kecamatan di Kabupaten Sukabumi, sekaligus menjadi nama ibu kota Kabupaten Sukabumi sendiri. Letaknya berada di sebelah barat daya kawasan kabupaten dan pesisir Samudra Hindia. (www.initempatwisata.co.id, 2016). Pantai Pelabuhan Ratu Sukabumi termasuk pantai teluk yang unik. Pantai Pelabuhan Ratu merupakan paduan antara pantai landai dan pantai curam. Di satu sisi dikelilingi hutan-hutan cagar alam, dan di sisi lainnya terdapat karang-karang terjal yang dihempas gelombang ombak. Legenda Nyi Roro Kidul yang disandingkan dengan Laut Selatan semakin melengkapi daya tarik dan menjadi magnet yang diharapkan akan menambah wisatawaan yang akan berkunjung dan menikmati fasilitas yang ada dan di tawarkan di Pantai Pelabuhan Ratu. Terlepas dari itu semua, hampir di tiap negara memiliki cerita-cerita legenda tersendiri yang akan memperkaya khazanah budaya negara itu sendiri. Soal benar atau tidaknya silahkan berpegang teguh pada keyakinan masing-masing dan saling menghormati pendapat orang lain. Tidak ada yang lebih mengetahui suatu kebenaran hanya Allah SWT sebagai pencipta alam semesta beserta isinya.

Entah ini sebagai suatu wujud dari kearifan lokal sehingga manajemen Hotel Samudera Beach memberikan kamar khusus yaitu kamar 308 sebagai wujud penghormatan bagi Nyi Roro Kidul dan menjadi image dan daya tarik tersendiri untuk mampu mendongkrak jumlah wisatawan sehigga kearifan lokal yang melekat pada mitos tersebut harus tetap dilestarikan dan dijaga.

Dimensi dalam kearifan lokal yang ada di pantai Pelabuhan Ratu adalah :

\section{Dimensi pengetahuan lokal}

Masyarakat yang berada di sekitar pantai Pelabuhan ratu memiliki mitos bahwa legenda Nyi Loro Kidul merupakan asset yang bisa menghasilkan pendapatan dari banyaknya kunjungan wisataawan. Keberadaan kamar di 308 di sebuah hotel di daerah pantai dianggap sebagai singasana dan tempat peristirahatan ratu tersebut.

\section{Dimensi nilai lokal}

Masyarakat sekitar memiliki aturan atau nilai-nilai yang di sepakati bersama tentang mitos tersebut dengan berupaya menjaga kelesatarian dengan menjaga dan merawat tempat yang ada hubungannya dengan legenda tersebut. Sebelum adanya kesepakatan bersama antara para ulama setempat dengan pemerintah daerah sebagai wujud kemusrikan walaupun tujuan utama sebagai ungkapan rasa syukur kepada Tuhan Yang Maha Esa. Setiap tahun di tanggal 6 April masyarakat menyakini bahwa dengan melakukan ritual upacara adat Labuh Saji ke tengah laut dengan membawa sesajen dan kepala kerbau itu merupakan penghormatan kepada kanjeng Nyi Roro Kidul sebagai ratu penguasa pantai selatan. 


\section{Dimensi keterampilan lokal}

Masyarakat sekitar memiliki keterampilan lokal dengan upaya menghasilkan produk cenderamata yang ada hubungannya dengan Pantai laut Pelabuhan Ratu atau cerita-cerita yang ada hubungannya dengan mitos Nyi Loro Kidul.

\section{Dimensi sumber daya lokal}

Masyarakat sekitar berusaha agar sumber daya lokal berupa peningglan yang ada hubungannya dengan mitos Nyi Roro Kidul tetap terjaga dan tidak punah. Seperti menjaga merawat tempat patilasan Nyi Roro Kidul di daerah Karang Hawu.

\section{Pantai Palabuan Ratu}

Pelabuhan Ratu memenuhu kreteria sebagai desa wisata karena memiliki fakta yang bisa masuk ke dalam syarat desa wisata diantaranya Memiliki potensi keunikan dan daya tarik wisata yang khas (sebagai atraksi wisata), baik berupa karakter fisik lingkungan alam pedesaan maupun kehidupan sosial budaya kemasyarakatan. Pantai ini memberi suguhan panorama yang menawan, berbalut udara sejuk dan pasir yang terhampar luas. Di pantai ini akan dijumpai bebatuan kiarang terjal yang menjorol ke laut serta hutan cagar alam pada sisi lainnya. Deburan ombak yang kencang menghantam karang semakin menambah panorama indah pantau pelabuhan Ratu di Sukabumi.

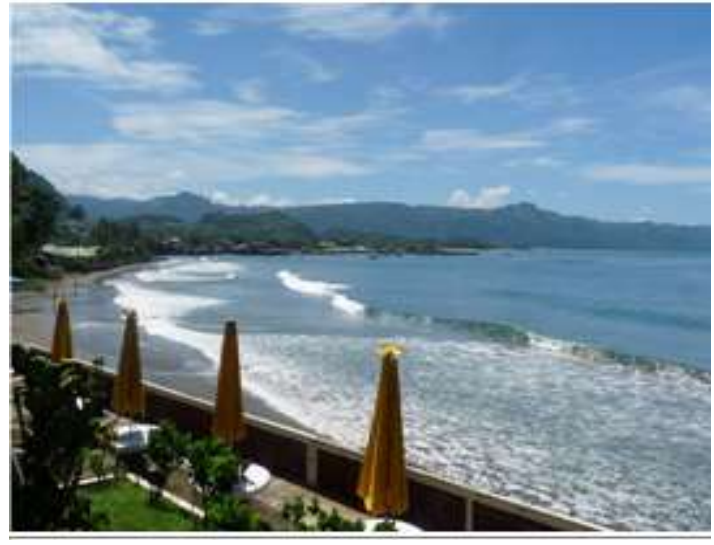

Gambar. 1 Pantai Pelabuhan Ratu (Junianto \& Handoko, 23 juli 2015)

\section{Scuba Diving}

Keindahan alam bawah laut Pelabuhan Ratu adalah salah satu yang menawan meski dikenal dengan arus laut dan ombak yang besar.

Beberapa spot diving yang terkenal diantaranya Sodong, Parat, Karang Antuk dan Batu Kuak. Dari ke tiga spot tersebut yang menjadi favorit adalah Karang Atuk. Eksplorasi pesona ekosistem bawah lautnya yang menawan dan aneka spesies ikan warna-warni yang indah dan terumbu karang menambah pesona diving ini.

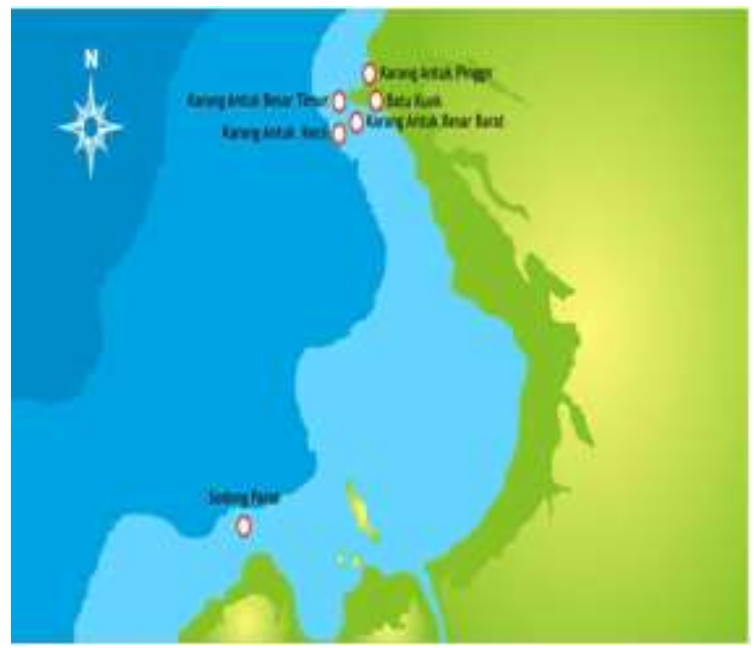

Gambar. 2. Diving di Pelabuhan Ratu (Junianto \& Handoko, 23 juli 2015) 


\section{Goa Lalay}

Ketika hari menjelang senja pada sekitar pukul 5 sore, gerombolan kelelawar biasanya akan mulai terbang keluar dari dalam gua tersebut. Lokasi goa yang hanya berjarak beberapa meter dari bibir pantai memungkinkan Anda untuk dapat menikmati sunset di Pelabuhan Ratu sekaligus menyaksikan atraksi ribuan kelelawar terbang yang sungguh unik tersebut

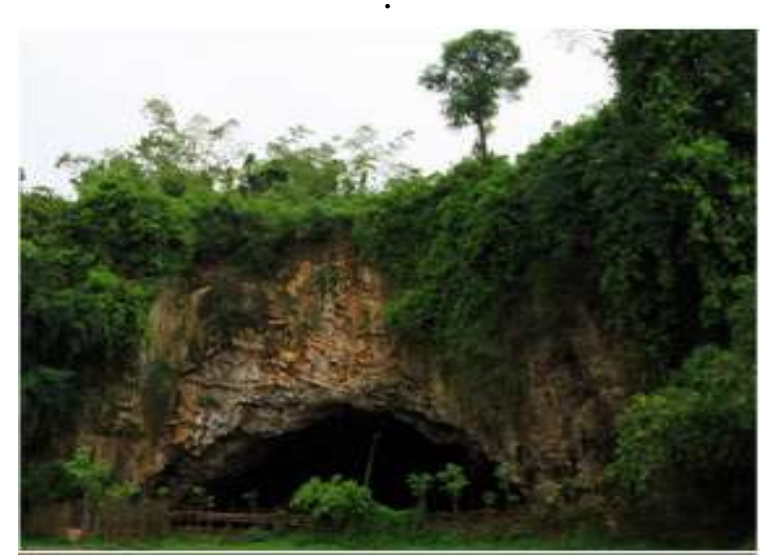

Gambar. 3. Goa Lalay di Pelabuhan Ratu (Junianto \& Handoko, 23 juli 2015)

\section{Pantai Cimaja}

Inilah pantai yang berlokasi dekat dengan pantai Pelabuhan Ratu di Sukabumi dan menjadi salah satu tempat Surfing paling favorit bagi para peselancar. Pantai ini tidak asing di kalangan surfer nasional dan internasional. Pantai Cimaja memiliki ombak yang besar dengan ketinggian ombak hingga mencapai 4 meter. Beberapa kompetisi surfing pernah terselenggara di pantai ini.

\section{Pantai Karang Hawu}

Pantai Karang hawu terletak di pelabuhan Ratu sekitar 75 kilometer arah selatan Kota Sukabumi. Nama Karang hawu berasal dari adanya gugusan batu karang yang menyerupai hawu atau tungku di lokasi itu. Di belakang garis pantai, menyembul bukit-bukit rindang oleh pepohonan Konon menurut cerita bahwa batuan keras berbentuk lempengan yang menjorok ke laut merupakan terumbu karang yang telat mati dan mengeras dan di percaya sebagai singgasana rayu laut selatan yang dikeramatkan oleh warga lokal sebagai salah satunya makam atau petilasan Ratu Nyi Roro Kidul.

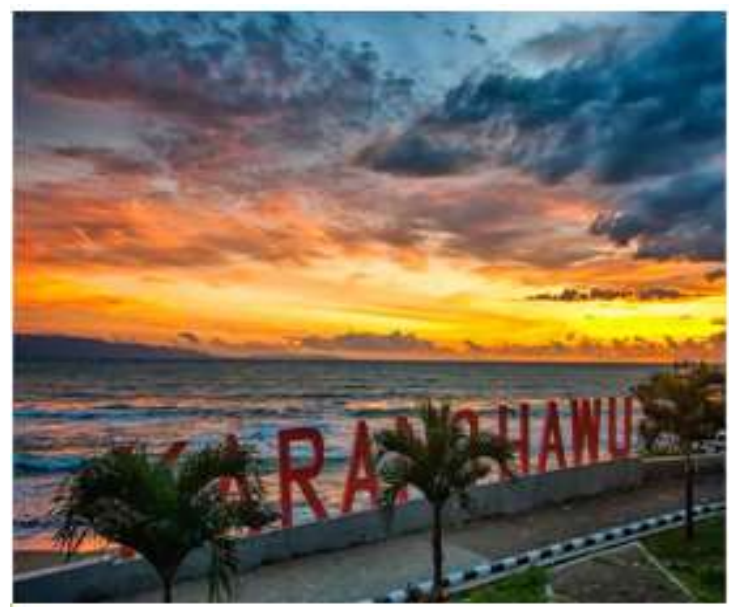

Gambar. 5. Pantai Karang Hawu (Junianto \& Handoko, 23 juli 2015)

\section{Pemandian Air Panas Cisolok}

Keunikan air panas Cosolok adalah adanya air panas yang menyembur keluar melalui bebatuan dengan tiga titik semburan. Air panas yang keluar dari titik sembur ini bersuhu tinggi mencapai 80 derajat celcius dan uniknya lagi biasanya air panas akan meuncul di daerah pegunungan tapi di lokasi ini jusrtu air panas menyembur bukan karena dekat dengan pegunungan.Satu hal keunikan yang tidak bisa dipungkiri yaitu air panas Cisolok ini tidak mengandung belerang melainkan berasal dari Geyser bumi dan di percaya bila mandi atau berendam di air panas ini bisa menyehatkan kulit. 


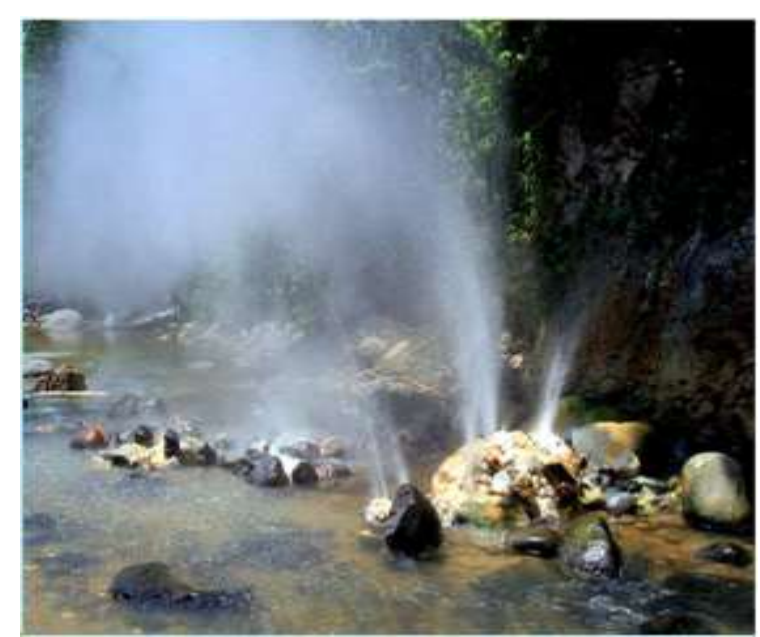

Gambar. 6. Air Panas Cisolok (Junianto \& Handoko, 23 juli 2015)

Memiliki dukungan dan kesiapan fasilitas pendukung kepariwisataan terkait dengan kegiatan wisata pedesaan, yang antara lain dapat berupa: akomodasi/penginapan, ruang interaksi masyarakat dengan wisatawan atau tamu, atau fasilitas pendukung lainnya. Salah satu hotel yang berada di lokasi Pantai Pelabuhan Ratu yang tertua dan terkenal adalah Hotel Inna Samudera. Hotel ini merupakan saksi bisu ada tidaknya keberadaan Nyi Roro Kidul. Hotel ini didirikan pada tahun 1962 oleh Presiden Soekarno. Hotel ini sempat menyaingi beberapa hotel di Bali karena fasilitas dan kemegahannya. dengan bangunan fisik sebanyak 8 tingkat dan memiliki 106 kamar yang dibangu diatas lahan seluas $60 \mathrm{H}$ dan terletak di Jl. Raya Cisolok KM 7 Pelabuhan Ratu_Sukabumi West JavaIndonesia Call service (0266) 431200,431201 letak bangunan memanjang dari timur ke Barat bertulang beton dan menghadap ke samuderta Hindia (Innasanudera

beachhotel.blogspot.com,2016) Salah satu kamar yang ada di hotel tersebut yang bernomor 308 memiliki daya tarik dan mistik tersendiri bagi para wisatawan, kadang wisatawan hanya ingin sekedar mengintip dan merasakan suasana yang mencekam sebagai uji nyali jika masuk atau sekedar melewati kamar tersebut.

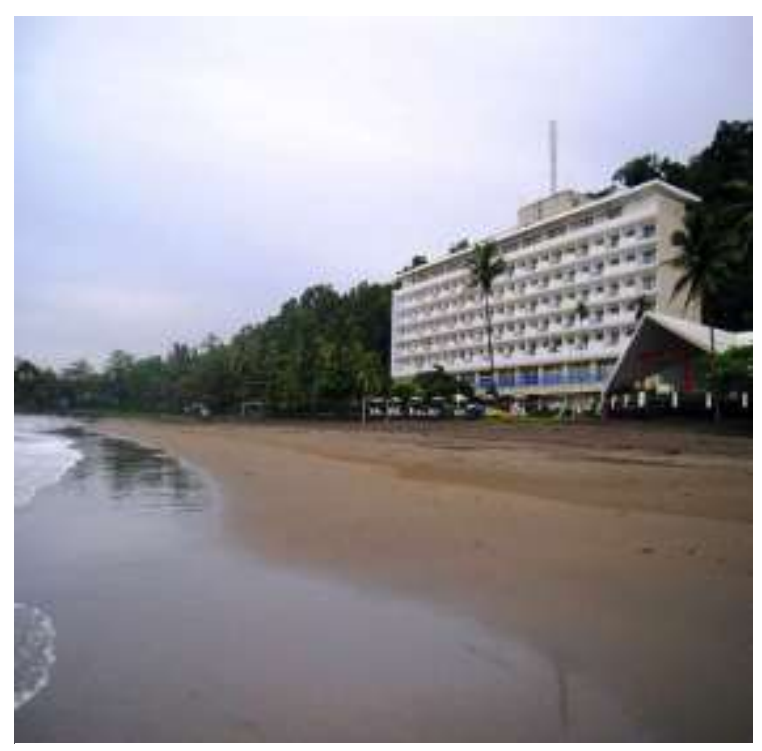

Gambar. 7. Inna Samudera Beach Hotel (http://bandung.panduanwisata.id/, 2016).

Tidak bisa di pungkiri keberadaan mitos Nyi Roro Kidul yang mendiami kamar 308 ini menjadi suatu kekuatan bagi hotel ini untuk bisa bertahan hidup sampai sekarang di tengah banyaknya hotel-hotel yang berdiri baru di kawasan tersebut.

Salah satu bukti bahwa Pelabuhan Ratu memiliki interaksi dengan pasar (wisatawan) tercermin dari kunjungan wisatawan ke lokasi desa tersebut. Menurut informasi yang di dapat dari Humas Badan Penyelamat Wisata Turta (Balawista) Kabupaten Sukabumi di tahun 2015 (m.antaranews.com, 2016) menjelang ramadhan atau dalam adat sunda disebut "papajar" dalam kurun waktu sepekan dan di H-1 menjelang ramadhan jumlah pengunjung bisa mencapai 3.000 orang. Ini membuktikan bahwa Pelabuhan Ratu 
memiliki magnet yang bisa menyedot pengunjung terlepas dari ada tidaknya sosok Nyi Roro Kidul yang melegenda tersebut dan sudah membawa Kabupaten Sukabumi memperoleh kontribusi asset dari hasil tiket kunjungan yang bisa di kelola untuk pembangunan daerah tersebut. Yang terpenting kearifan lokal yang di pegang selama ini harus di lestarikan sehingga julukan desa wisata yang menarik dan unik masih tetap di pertahankan.

Salah satu bukti adanya dukungan, inisiatif dan partisipasi masyarakat setempat terhadap pengembangan desa tersebut terkait dengan kegiatan kepariwisataan (sebagai desa) di pantai Pelabuhan Ratu terbukti dengan promosi baik yang dilakukan dari mulut ke mulut atau melalui media social yang berupaya untuk memperkenalkan dan mempromosikan akan keindahan dan menjadikan pilihan yang tepat bagi para wisataan dalam mengisi liburan atau sekedar ingin tau dan mencoba alternatif pilihan tempat wisata.

\section{KESIMPULAN}

Dari kajian dan penemuan yang di peroleh oleh penulis dan di dukung oleh referensi yang relevan, maka dapat di simpulkan bahwa Pantai Pelabuhan Ratu memilikit magnet yang bisa menarik wisataan untuk mau berkunjung, salah satu magnet daya tariknya diantaranya adanya mitos keberadaan Nyi Roro Kidul, memiliki kreteria dimensi dalam kearifan lokal diantaranya Dimensi pengetahuan lokal, dimensi nilai lokal, dimensi keterampilan lokal dan dimensi sumber daya lokal yang mendukung dan menjadikan Pelabuhan Ratu masuk ke dalam syarat desa wisata yang berpengaruh pada kemampuan untuk berkontribusi dalam menghasilkan asset untuk pemerintah daerah maupun masyarakat sekitar.

\section{DAFTAR PUSTAKA}

Atmoko, P. H. (2016). http://download.portalgaruda.org/a rticle.php? article $=392436 \&$ val $=63$ $52 \&$ title $=$ STRATEGI\%20PENGEM BANGAN\%20POTENSI\%20DESA \%20WISATA\%20BRAJAN\%20KAB UPATEN\%20SLEMAN. Retrieved 122016

gurupendidikan.com. (2016).

Herdiansyah, H. (2010). Metodologi

Penelitian Kualitatif Untuk Ilmu-

Ilmu Sosial. Jakarta: Salemba

Hummaika.

http://bandung.panduanwisata.id/. (2016). http://download.portalgaruda.org/article.p $h p ?$ article $=392436 \&$ val $=6352 \&$ titl $e=$ STRATEGI\%2OPENGEMBANGA N\%20POTENSI\%20DESA\%2OWIS ATA\%20BRAJAN\%20KABUPATEN \%20SLEMAN. (2016). Retrieved from

http://kisahasalusul.blogspot.com. (2015).

Retrieved 12 2016, from

http://kisahasalusul.blogspot.com/20

15/03/asal-usul-nyi-roro-kidulmenurut-islam.html.

http://www.indospiritual.com. (2016). http://www.indospiritual.com/artikel _legenda-nyi-roro-kidul-danmisteri-kamar-308-samudra-beachhotel.html.

Innasanuderabeachhotel.blogspot.com. (2016).

Junianto, B., \& Handoko, D. (23 juli 2015). Fakta Unik Pelabuhan Ratu. m.news.viva.co.id. m.antaranews.com. (2016). 
Muzayana, L. (2016).

http://www.academia.edu/5442275/

definisi aset dan liabilities.

Ningsih, S. (2001). Perlakuan Akuntansi

Sumber Daya Manusia: Assets

Sekaligus Investor Bagi Perusahaan.

Akuntansi dan Investasi Vol. 2 NO.2

, 13-26.

Ridwan. (2007). Landasan keilmuan

kearifan Lokal. Jurnal Study Islam

dan Budaya , 27-38.

Sugiono. (2012). Penelitian Kuantitatif dan kualitatif. Bandung: AlfaBeta.

Suryani, I. (2014). Kearifan Lokal. Musawa Vol.13 No.2 Desember .

Undang-Undang N0. 23. (2009).

www.initempatwisata.co.id. (2016). 